\title{
Pengetahuan dan Sikap Manusia Terhadap Isu Lingkungan
}

\author{
Ashary Alam, Muhammad Ardi, Ahmad Rifqi Asrib \\ PKLH PPS Universitas Negeri Makassar, Sulawesi Selatan, Indonesia \\ asharyalam@gmail.com
}

2018 - UEJ Program Studi Pendidikan Kependudukan dan Lingkungan Hidup

Universitas Negeri Makassar. Ini adalah artikel dengan akses terbuka dibawah Licensi CC BY-NC-4.0 (http:/creativecommons.org/licenses/by-nc/4.0)

\begin{abstract}
.
Environmental issues are problems that arise from the results of greedy human activities in exploiting nature. Many environmental issues have made humans vulnerable to disasters. The utilization of energy resources carried out by humans today results in air pollution, the greenhouse effect, and global warming. The environment becomes degraded due to human activation, a degraded environment will only have a negative impact on human life. This article discusses human knowledge and attitudes towards environmental issues. Environmental knowledge is general knowledge about facts, concepts, or relationships related to the surrounding environment and its ecosystem. Every human being has different environmental knowledge because it is influenced by factors of education, experience, information, the area of residence. Knowledge of the environment that humans have will support their environmental attitudes and behavior. Every environmental issue that occurs will bring up two kinds of attitudes in the community, namely positive and negative attitudes. Every attitude possessed by humans will determine what steps they will choose in facing environmental issues, such as turning off lights, turning off electronic equipment, choosing vehicles with minimal emissions.
\end{abstract}

Keywords: Environmental Issues, Environmental Knowledge, Environmental Attitudes.

\section{PENDAHULUAN}

Pertumbuhan penduduk yang meningkat setiap tahunnya menimbulkan berbagai isu lingkungan. Isu lingkungan yang ada saat ini bukan hanya dihadapi oleh satu Negara saja tetapi seluruh Negara yang ada di Dunia ini sedang menghadapi isu lingkungan. Namun isu lingkungan sangat dirasakan oleh Negara terbelakang. Pada tahun 2012 warga Negara Nigeria kesulitan untuk mendapatkan air bersih bahkan hanya 54\% dari warga mereka yang bisa meminum air bersih, dan pada tahun yang sama hanya 19\% yang memiliki akses toilet (Lasagna et al., 2015).

Isu lingkungan yang terjadi merupakan hasil dari aktifitas manusia. Aktifitas manusia yang terlalu rakus dalam mengeksploitasi alam telah menyebabkan penipisan sumber daya alam. Pemanfaatan batu bara yang merupakan sumber daya energi banyak digunakan dalam kehidupan manusia telah memberikan dampak negatif terhadap lingkungan seperti efek rumah kaca, deposisi asam, produksi asap perkotaan, emisi beracun, pencucian logam berat ke permukaan dan air tanah. Sebuah studi yang dilakukan di Eropa selama 10 tahun menunjukkan bahwa penggunaan batu bara dalam memproduksi listrik ternyata lebih banyak mengeluarkan biaya sebanyak 30\% dibandingkan dengan menggunakan gas jika biaya kerusakan lingkungan dan kesehatan juga dimasukan kedalam perhitungan (Nelson, 2013).

Isu lingkungan yang dapat mengakibatkan kerentanan terhadap bencana telah dirangkum oleh (Sadhu, Garg, \& Kumar, 2018) yaitu polusi udara, pengelolaan limbah yang buruk, kelangkaan air yang meningkat, menurunnya air tanah, pencemaran air, pelestarian dan kualitas hutan, hilangnya keanekaragaman hayati, degradasi lahan, perubahan iklim global, polusi, degradasi lingkungan, berkurangnya sumber daya alam, dan makanan hasil rekayasa genetika. Penyebab terjadi lingkungan terdegradasi ada beberapa faktor yaitu konsumsi energi, pertumbuhan ekonomi dan total populasi (Ahmed et al. 2015) dalam (Rehman \& Rashid, 2017).

Peristiwa salinisasi atau yang disebut sebagai peningkatan jumlah zat garam yang terkandung dalam tanah juga merupakan salah isu lingkungan yang dihadapi saat ini. Permasalahan salinisasi ini menjadi ancaman dalam ketahanan pangan nasional. Salinisasi ini menjadi permasalahan yang serius, hal ini dapat ditinjau dari jumlah lahan irigasi dunia yang terinfeksi salinisasi adalah sebanyak 33\% (A. 
Singh, 2017). Sehingga dari permasalah salinisasi ini haruslah ditemukan sebuah model teknologi / solusi yang dapat mengurangi jumlah kadar garam yang terkandung dalam tanah.

Setiap manusia membutuhkan sumber daya energi yang dapat mendukung aktifitasnya. Seiring dengan meningkatnya populasi manusia maka jumlah permintaan sumber daya energi juga ikut meningkat. Setiap penggunaan sumber daya energi selalu berdampak terhadap lingkungan. Dampak dari penggunaan sumber daya energi yang ada saat ini adalah seperti pencemaran udara, efek rumah kaca, pemanasan global. Saat ini telah banyak manusia yang beralih menggunakan sumber daya energi yang terbarukan, tapi tetap saja sumber daya tersebut tetap memiliki dampak terhadap lingkungan, misalnya saja seperti pembangkit listrik tenaga angin memiliki dampak seperti suara yang dihasilkan dari alat tersebut dapat menganggu kesehatan manusia(Towler, 2014).

Saat ini lingkungan dan kesehatan manusia telah terdegradasi dengan munculnya polutan ke dalam lingkungan. Pencemar Organik Persisten (POP) merupakan salah satu pencemar kimia beracun yang saat ini ada dilingkungan kita dan telah masuk juga kedalam tubuh manusia, bahkan ada kandungan POP yang ditemukan pada tubuh bayi yang baru lahir. POP ini dapat memberikan dampak pada kesehatan manusia seperti Efek Aditif dan Sinergis, Gangguan Endokrin, Masalah Reproduksi, Masalah Kardiovaskular, Kanker, Obesitas.Diabetes (Alharbi, Basheer, Khattab, \& Ali, 2018).

Pencemaran lingkungan adalah salah satu dari isu lingkungan yang ada saat ini. Salah satu zat pencemar yang diketahui adalah Karbondioksida $\left(\mathrm{CO}_{2}\right)$. Ketika jumlah $\mathrm{CO}_{2}$ yang ada dilingkungan berada diatas ambang batas maka hal tersebut akan mengganggu kesemibangan $\mathrm{pH}$ yang ada pada lingkungan tersebut. Hal tersebut dapat kita lihat pada permasalahan pengasaman laut yang terjadi karena diakibatkan tingginya jumlah $\mathrm{CO}_{2}$. Pengasaman laut juga memberikan dampak negatif bagi industr perikanan dan kerang (Spence, Pidgeon, \& Pearson, 2018). Berdasarkan hal tersebut kita dapat melihat bahwa permasalah lingkungan yang awalnya berasal dari aktifitas manusia yang memproduksi $\mathrm{CO}_{2}$ dengan jumlah yang banyak menyebabkan terjadinya pengasaman laut, akhirnya permasalahan tersebut berdampak kembali pada manusia itu sendiri.

Perluasan pertanian sebagai dampak dari meningkatnya permintaan makanan mengakibatkan terjadinya pembebasan lahan hutan. Penggundulan hutan atau deforestasi merupakan salah satu dari indikator terjadinya degradasi lingkungan (Zambrano-Monserrate, Carvajal-Lara, Urgilés-Sanchez, \& Ruano, 2018). Isu lingkungan sangat berkaitan erat dengan pertumbuhan ekonomi, karena setiap dilakukan pembangunan ekonomi akan memberikan dampak negative terhadap lingkungaan. Hal tersebut sesuai dengan penelitian yang dilakukan di Afrika Barat bahwa pertumbuhan ekonomi dalam jangka pendek meningkatkan emisi karbodioksida dan sampah (Adu \& Denkyirah, 2018).

Berbagai isu lingkungan menuntut umat manusia untuk memiliki pengetahuan dan sikap terhadap isu lingkungan. Pengetahuan dan sikap inilah yang diharapkan dapat membentuk prilaku lingkungan. Artikel ini akan membahas mengenai pengetahuan dan sikap manusia terhadap isu lingkungan.

\section{PENGETAHUAN MANUSIA TENTANG ISU LINGKUNGAN}

Fryxell and Lo (2003) dalam (Paço \& Lavrador, 2017) mendefenisikan pengetahuan lingkungan sebagai pengetahuan umum tentang fakta, konsep, atau hubungan terkait dengan lingkungan sekitar dan ekosistemnya. Berdasarkan definisi tersebut kita dapat memahami bahwa pengetahuan lingkungan adalah sebuah pengetahuan yang pada dasarnya berisi mengenai fakta tentang manusia dan lingkungannya, konsep tentang manusia dan lingkungannya, serta hubungan antara manusia dan lingkungannya. Sehingga pengetahuan lingkugan ini akan menjadi dasar dari sebuah perilaku lingkungan yang dimiliki manusia, hal tersebut sesuai dengan Penelitian yang dilakukan di wilayah inggris dan inggris timur tentang pengetahuan lingkungan. Hasil penelitian menunjukkan bahwa pengetahuan tentang green house gas emissions dan energy saving memiliki hubungan positif dengan tindakan mengurangi konsumsi energi (Pothitou, Hanna, \& Chalvatzis, 2016). Ini berarti bahwa pengetahuan memiliki peran penting dalam membawa perubahan prilaku dalam diri seseorang. Pendidikan lingkungan hidup merupakan sebuah jalan yang dapat ditempuh untuk menanamkan pengetahuan tentang lingkungan tersebut.

Isu lingkungan yang akarnya berasal dari aktifitas manusia menuntut manusia untuk memiliki pengetahuan terhadap isu lingkungan yang mereka hadapi. Sebuah penelitian yang dilakukan di Bogota, Kolombia terhadap masyarakat perkotaan menunjukkan bahwa $52.05 \%$ merasakan suhu lebih panas, $33.72 \%$ merasakan terjadinya penurunan curah hujan (Pardo Martínez, Alfonso Piña, \& Moreno, 2018). 
Lebih lanjut Pardo Martínez menggali informasi mengenai pemahaman masyarakat mengenai penyebab terjadinya perubahan iklim, ternyata $13,67 \%$ setuju bahwa perubahan iklim disebabkan oleh fenomena alam, 31,80 setuju bahwa perubahan iklim disebabkan oleh kehendak Tuhan, dan 56,32\% setuju bahwa perubahan iklim disebabkan oleh tindakan manusia.

Sebuah studi di Indonesia yang mencoba untuk melihat perbedaan pengetahuan mahasiswa tentang isu lingkungan global dan isu lingkungan lokal menunjukkan bahwa pengetahuan mahasiswa tentang isu lingkungan lokal lebih tinggi dibandingkan isu lingkungan global. Kurangnya pengetahuan mahasiswa akan isu lingkungan global dapat dipengaruhi oleh kurangnya informasi yang diterima tentang isu lingkungan global (Pertiwi \& Dirawan, 2013). Pengetahuan lingkungan secara umum dapat ditambah dengan beberapa pengetahuan spesifik seperti pengetahuan eco-label untuk mewujudkan perilaku lingkungan (Taufique, Siwar, Chamhuri, \& Sarah, 2016). Mengacu pada (Pertiwi \& Dirawan, 2013) dan (Taufique et al., 2016) kita dapat membuat kesimpulan bahwa untuk memberikan pengetahuan lingkungan kepada mahasiswa, masyarakat, atau siapa saja berbagai informasi mengenai isu lingkungan baik itu secara global maupun lokal harus tersampaikan kepada mereka serta harus ditambahkan dengan pemberian pengetahuan spesifik seperti eco-label.

Penelitian yang dilakukan oleh (Pothitou et al., 2016) tentang pengaruh pengetahuan lingkungan dan energi terhadap prilaku hemat energi telah menunjukkan bahwa pengetahuan memiliki peran penting dalam aksi hemat energi. Pada penelitian lain menunjukkan sebuah bahwa sikap akan diterjemahkan kedalam bentuk aksi tidak menyerah untuk mengurangi konsumsi energy (Sapci \& Considine, 2014). Pengetahuan yang dimiliki oleh seseorang akan mempengaruhi sikap yang dimiliki, pengetahuan juga akan berpengaruh pada prilaku seseorang yang berkaitan dengan penghematan energi. Meskipun prilaku seseorang ini adalah hal yang kecil seperti kebiasaan "mematikan lampu yang tidak digunakan" tetapi jika hal tersebut dilakukan oleh banyak orang, hal tersebut akan berpengaruh pada lingkungan dan perekonomian.

Pengetahuan tentang isu lingkungan yang dimiliki setiap manusia berbeda. Perbedaan pengetahuan itu dipengaruhi faktor pendidikan, pengalaman, informasi, wilayah tempat tinggal. Sebuah hasil studi di Jawa Tengah yang membandingkan pe rilaku lingkungan hidup antara siswa dari sekolah adiwiyata perkotaan dan pedesaan menunjukkan bahwa terdapat perbedaan perilaku peduli lingkungan. Perbedaan perilaku peduli lingkungan tersebut dipengaruhi oleh beberapa faktor yaitu faktor individu siswa, luas sekolah, kegiatan lingkungan sekolah adiwiyata, dan fasilitas sarana prasarana sekolah adiwiyata tersebut (Nugroho, Hariyanto, \& Suharini, 2017).

Berbicara tentang perbedaan pengetahuan lingkungan, kita dapat bercermin pada perbedaan pengetahuan lingkungan yang dimiliki oleh remaja Nigeria dan Iran. Berdasarkan penelitian yang dilakukan di Nigeria menunjukkan bahwa 67,76\% memiliki pengetahuan lingkungan secara umum tapi hanya $45,96 \%$ yang memiliki pengetahuan tentang keanekaragaman hayati, berbeda dengan Iran yang menunjukkan pengetahuan tentang keanekaragaman hayati berada di skor tertinggi (Abiolu, 2018). Perbedaan pengetahuan lingkungan juga ditunjukan dari hasil studi pada mahasiswa Universitas yang ada di Iran, mahasiswa yang berasal dari teknik sipil, kesehatan lingkungan, farmasi, ilmu pertanian dan sumber daya alam mendapatkan hasil yang lebih tinggi dibandingkan mahasiswa yang berasal dari ilmu sosial dan manusia, ilmu administrasi, teologi, ilmu politik dan sains, arsitektur dan seni (Salehi, Nejad, Mahmoudi, \& Burkart, 2016).

\section{SIKAP MANUSIA TENTANG ISU LINGKUNGAN}

Menurut (Zareie \& Jafari Navimipour, 2016) ada enam hal yang mempengaruhi prilaku seseorang dalam prilaku lingkungan yaitu sikap, kesadaran, nilai lingkungan, informasi, skil, tanggung jawab. Dari hasil penelitiannya menunjukkan bahwa informasi memiliki pengaruh terbesar terhadap prilaku seseorang, kemudian sikap berada di peringkat kedua. Hal ini sesuai dengan (Yurttaş \& Sülün, 2010) yang menyatakan bahwa peningkatan pengetahuan lingkungan akan membantu meningkatkan sikap lingkungan.

Salah satu langkah yang dapat dilakukan untuk melakukan konservasi lingkungan yang telah terdegradasi adalah dengan meningkatkan sikap lingkungan. Saat ini yang menjadi tantangan dalam melakukan konservasi alam adalah pertentangan antara tujuan konservasi alam dan preferensi manusia. Manusia dalam menilai alam hanya berdasarkan tujuan mereka masing-masing (misalnya alam hanya dipandang sebagai tempat rekreasi), hal itu tentu berbeda dari tujuan konservasi alam (Kiley, Ainsworth, van Dongen, \& Weston, 2017). 
Isu mengenai perubahan iklim telah menjadi pusat perhatian dunia, hal ini dapat dilihat dari banyaknya penelitian yang dilakukan terkait perubahan iklim. Perubahan iklim merupakan permasalahan yang sangat kompleks karena berkaitan dengan akumulasi karbondioksida, suhu air laut, tekanan udara bumi, dan beberapa factor lainnya yang tidak dikenal. Saat ini faktor aktifitas manusia juga dimasukan kedalam salah satu faktor yang menyebabkan terjadinya perubahan iklim, namun beberapa manusia saat ini belum menyadari, bahkan mereka mengatakan bahwa tidak ada hubungan antara perilaku konsumsi energi mereka dengan perubahan iklim yang terjadi (Smith, Kim, \& Son, 2017).

Isu lingkungan seperti perubahan iklim yang terjadi saat ini memunculkan dua macam sikap dalam diri masyarakat yaitu sikap negatif dan sikap positif. Sikap positif pada diri masyarakat akan percaya pada aksi mitigasi mengentikan perubahan iklim, sedangkan sikap negatif dalam diri masyarakat akan mempercayakan pemecahan masalah perubahan iklim pada orang lain. Sikap positif dalam diri masyarakat juga akan memunculkan willingness to act seperti keinginan untuk mematikan peralatan elektronik yang tidak digunakan (Hermans \& Korhonen, 2017).

Salah satu penyumbang karbondioksida di wilayah perkotaan adalah kendaraan bermotor. Seiring dengan pertumbuhan penduduk maka jumlah kendaraan bermotor juga ikut meningkat. Sikap lingkungan yang ada pada diri seseorang akan membuat mereka memikirkan standar kendaraan yang sesuai seperti emisi kendaraan, efisiensi bahan bakar, kapasitas kursi (Beck, Rose, \& Hensher, 2013). Agar dapat meminimalisir karbondioksida yang ada diudara maka manusia harus menggunakan energi bahan bakar secara efisien.

Setidaknya ada beberapa faktor yang membentuk sikap dalam diri manusia yaitu faktor sosial ekonomi, perasaaan, kepercayaan, pengetahuan dan pengalaman. Sikap dalam diri setiap manusia berbeda bergantung pada gender, pekerjaan, dan status kependudukan (Acuña-Marrero et al., 2018). Sebuah studi pada sikap petani yang berubah menjadi berorientasi konservasi pada kegiatan pertanian mereka ternyata dipengaruhi olah faktor sosial dan masyarakat (Sulemana \& James, 2014). Sesuai (Acuña-Marrero et al., 2018) dan (Sulemana \& James, 2014) kita dapat mengatakan bahwa kondisi masyarakat petani yang melakukan kegiatan pelestarian lingkungan akan menjadi sebuah stimulus kepada petani lain yang belum melakukan kegiatan pelestarian lingkungan.

Berbagai produk yang ada di masyarakat merupakan produk yang dapat menghasilkan sampah sehingga saat ini salah satu isu lingkungan adalah permasalahan sampah. Manusia memainkan peran penting dalam melakukan pengelolaan sampah mereka, seperti pemisahan, penyimpanan, pengumpulan, daur ulang, dan pembuangan. Di Amerika Serikat dan Uni Eropa yang merupakan negara maju, sekitar 60-80\% sampah mereka daur ulang dari seluruh total sampah yang mereka produksi setiap harinya. Hal tersebut berbeda dengan negara berkembang seperti iran yang hanya mampu untuk mendaur ulang sebanyak $8 \%$ dari total sampah mereka. Pengetahuan, sikap, dan perilaku dari daur ulang dan pemisahan sampah dipengaruhi oleh beberapa faktor yaitu usia, tingkat pendidikan, gender, pekerjaan. Sikap dan perilaku daur ulang dan pemisahan sampah dapat ditingkatkan dengan menyediakan sarana dan prasarana yang mendukung (Babaei et al., 2015).

Berbicara tentang permasalahan sampah saat ini ada istilah Zero Waste yang merupakan sebuah pendekatan yang berkelanjutan yang bertujuan untuk mengatur dan menghilangkan sampah. Setidaknya ada lima kategori yang ada dalam Zero Waste, yaitu (1) zero waste dalam administrasi dan manufaktur; (2) zero waste dalam sumber daya alam (3) nol emisi; (4) zero waste dalam kehidupan produk dan; (5) nol penggunaan racun (S. Singh, Ramakrishna, \& Gupta, 2017). Lebih lanjut, zero waste ini bertujuan untuk mendorong para produsen dan konsumen untuk melakukan aktifitasnya tanpa berkontribusi terhadap limbah. Dengan melakukan kampanye zero waste diharapakan dapat membentuk sikap kepada produsen dan konsumen, misalnya konsumen ingin beralih dari menggunakan kantong plastik untuk barang belanjaan mereka dengan menggunakan kantong dari kain yang mereka dapat gunakan lebih dari satu kali.

\section{KESIMPULAN}

Dari berbagai isu lingkungan yang terjadi hingga saat ini pengetahuan manusia lebih besar hanya memahami isu lingkungan lokal. Setiap pengetahuan lingkungan yang dimiliki oleh setiap manusia dipengaruhi oleh beberapa faktor seperti tingkat pendidikan, pengalaman, informasi, dan wilayah tempat tinggalnya. Pengetahuan yang dimiliki oleh manusia akan membawa perubahan pada perilaku mereka, seperti perilaku mematikan peralatan elektronik/lampu yang tidak digunakan bisa 
tercipta karena manusia tersebut memiliki pengetahuan tentang dampak dari penggunaan energi listrik secara tidak bertanggung jawab.

Setiap perilaku yang muncul dalam keseaharian manusia selain dipengaruhi oleh pengetahuan, ternyata dipengaruhi juga oleh sikap. Dari berbagai isu lingkungan yang terjadi akan memunculkan dua macam sikap dalam diri manusia yaitu sikap positif dan sikap negatif. Sikap positif akan membuat manusia tersebut merasa perlu untuk melakukan sebuah tindakan yang dapat mengatasi isu lingkungan. sikap lingkungan akan membuat manusia memikirkan dampak dari setiap apa yang akan mereka lakukan, misalnya ketika mereka ingin membeli kendaraan mobil, mereka akan mempertanyakan tentang jumlah emisi yang dikeluarkan mobil tersebut dan manusia yang memiliki sikap lingkungan cenderung untuk memilih mobil dengan emisi rendah. Adapun faktor yang membentuk sikap lingkungan itu sendiri adalah faktor sosial ekonomi, perasaaan, kepercayaan, pengetahuan dan pengalaman. Salah satu upaya yang bisa dilakukan untuk meningkatkan sikap lingkungan adalah dengan melakukan kampanye Zero Waste.

\section{Referensi}

Abiolu, O. A. (2018). Environmental knowledge and behavior of Nigerian youth: An assessment. Applied Environmental Education and Communication, 0(0), 1-15.

https://doi.org/10.1080/1533015X.2018.1432431

Acuña-Marrero, D., Cruz-Modino, R. de la, Smith, A. N. H., Salinas-de-León, P., Pawley, M. D. M., \& Anderson, M. J. (2018). Understanding human attitudes towards sharks to promote sustainable coexistence. Marine Policy, 91, 122-128. https://doi.org/10.1016/J.MARPOL.2018.02.018

Adu, D. T., \& Denkyirah, E. K. (2018). Economic growth and environmental pollution in West Africa: Testing the Environmental Kuznets Curve hypothesis. Kasetsart Journal of Social Sciences, 8-15. https://doi.org/10.1016/j.kjss.2017.12.008

Alharbi, O. M. L., Basheer, A. A., Khattab, R. A., \& Ali, I. (2018). Health and environmental effects of persistent organic pollutants. Journal of Molecular Liquids.

https://doi.org/10.1016/J.MOLLIQ.2018.05.029

Babaei, A. A., Alavi, N., Goudarzi, G., Teymouri, P., Ahmadi, K., \& Rafiee, M. (2015). Household recycling knowledge, attitudes and practices towards solid waste management. Resources, Conservation and Recycling, 102, 94-100. https://doi.org/10.1016/j.resconrec.2015.06.014

Beck, M. J., Rose, J. M., \& Hensher, D. A. (2013). Environmental attitudes and emissions charging: An example of policy implications for vehicle choice. Transportation Research Part A: Policy and Practice, 50, 171-182. https://doi.org/10.1016/j.tra.2013.01.015

Hermans, M., \& Korhonen, J. (2017). Ninth graders and climate change: Attitudes towards consequences, views on mitigation, and predictors of willingness to act. International Research in Geographical and Environmental Education, 26(3), 223-239. https://doi.org/10.1080/10382046.2017.1330035

Kiley, H. M., Ainsworth, G. B., van Dongen, W. F. D., \& Weston, M. A. (2017). Variation in public perceptions and attitudes towards terrestrial ecosystems. Science of the Total Environment, 590-591, 440-451. https://doi.org/10.1016/j.scitotenv.2016.12.179

Lasagna, M., Dino, G. A., Perotti, L., Spadafora, F., De Luca, D. A., Yadji, G., ... Moussa, K. (2015). Georesources and Environmental Problems in Niamey City (Niger): A Preliminary Sketch. Energy Procedia, 76, 67-76. https://doi.org/10.1016/j.egypro.2015.07.848

Nelson, P. F. (2013). Environmental issues: emissions, pollution control, assessment and management. In The Coal Handbook: Towards Cleaner Production (pp. 21-62). Elsevier.

https://doi.org/10.1533/9781782421177.1.21

Nugroho, M. A., Hariyanto, H., \& Suharini, E. (2017). Perilaku Peduli Lingkungan Siswa Sekolah

Adiwiyata Perdesaan Dan Perkotaan Di Jawa Tengah Tahun 2016. Edu Geography, 5(2), 26-34.

Paço, A., \& Lavrador, T. (2017). Environmental knowledge and attitudes and behaviours towards energy consumption. Journal of Environmental Management, 197, 384-392.

https://doi.org/10.1016/j.jenvman.2017.03.100

Pardo Martínez, C. I., Alfonso Piña, W. H., \& Moreno, S. F. (2018). Prevention, mitigation and adaptation to climate change from perspectives of urban population in an emerging economy. Journal of Cleaner Production, 178, 314-324. https://doi.org/10.1016/j.jclepro.2017.12.246 
Pertiwi, N., \& Dirawan, G. D. (2013). KNOWLEDGE OF ENGINEERING STUDENTS ON, 96(4), 1027 1030.

Pothitou, M., Hanna, R. F., \& Chalvatzis, K. J. (2016). Environmental knowledge, pro-environmental behaviour and energy savings in households: An empirical study. Applied Energy, 184, 1217-1229. https://doi.org/10.1016/j.apenergy.2016.06.017

Rehman, M. U., \& Rashid, M. (2017). Energy consumption to environmental degradation, the growth appetite in SAARC nations. Renewable Energy, 111, 284-294. https://doi.org/10.1016/j.renene.2017.03.100

Sadhu, S. D., Garg, M., \& Kumar, A. (2018). Major environmental issues and new materials. In New Polymer Nanocomposites for Environmental Remediation (pp. 77-97). Elsevier. https://doi.org/10.1016/B978-0-12-811033-1.00004-4

Salehi, S., Nejad, Z. P., Mahmoudi, H., \& Burkart, S. (2016). Knowledge of global climate change: view of Iranian university students. International Research in Geographical and Environmental Education, 25(3), 226-243. https://doi.org/10.1080/10382046.2016.1155322

Sapci, O., \& Considine, T. (2014). The link between environmental attitudes and energy consumption behavior. Journal of Behavioral and Experimental Economics, 52, 29-34. https://doi.org/10.1016/j.socec.2014.06.001

Singh, A. (2017). Managing the environmental problems of irrigated agriculture through the appraisal of groundwater recharge. Ecological Indicators, (November), 1-6. https://doi.org/10.1016/j.ecolind.2017.11.065

Singh, S., Ramakrishna, S., \& Gupta, M. K. (2017). Towards zero waste manufacturing: A multidisciplinary review. Journal of Cleaner Production, 168, 1230-1243. https://doi.org/10.1016/j.jclepro.2017.09.108

Smith, T. W., Kim, J., \& Son, J. (2017). Public Attitudes toward Climate Change and Other Environmental Issues across Countries. International Journal of Sociology, 47(1), 62-80. https://doi.org/10.1080/00207659.2017.1264837

Spence, E., Pidgeon, N., \& Pearson, P. (2018). UK public perceptions of Ocean Acidification - The importance of place and environmental identity. Marine Policy. https://doi.org/10.1016/j.marpol.2018.04.006

Sulemana, I., \& James, H. S. (2014). Farmer identity, ethical attitudes and environmental practices. Ecological Economics, 98, 49-61. https://doi.org/10.1016/j.ecolecon.2013.12.011

Taufique, K. M. R., Siwar, C., Chamhuri, N., \& Sarah, F. H. (2016). Integrating General Environmental Knowledge and Eco-Label Knowledge in Understanding Ecologically Conscious Consumer Behavior. Procedia Economics and Finance, 37(16), 39-45. https://doi.org/10.1016/S2212-5671(16)30090-9

Towler, B. F. (2014). Chapter 4 - Environmental Issues. In The Future of Energy (pp. 39-56). https://doi.org/10.1016/B978-0-12-801027-3.00004-X

Yurttaş, G. D., \& Sülün, Y. (2010). What are the most important environmental problems according to the second grade primary school students? Procedia - Social and Behavioral Sciences, 2(2), 1605-1609. https://doi.org/10.1016/j.sbspro.2010.03.244

Zambrano-Monserrate, M. A., Carvajal-Lara, C., Urgilés-Sanchez, R., \& Ruano, M. A. (2018). Deforestation as an indicator of environmental degradation: Analysis of five European countries. Ecological Indicators, 90(February), 1-8. https://doi.org/10.1016/j.ecolind.2018.02.049

Zareie, B., \& Jafari Navimipour, N. (2016). The impact of electronic environmental knowledge on the environmental behaviors of people. Computers in Human Behavior, 59, 1-8. https://doi.org/10.1016/j.chb.2016.01.025 